\title{
Scleractinian coral diseases in south Florida: incidence, species susceptibility, and mortality
}

\author{
Jill L. Borger \\ Rosenstiel School of Marine and Atmospheric Science, Division of Marine Biology and Fisheries, \\ 4600 Rickenbacker Causeway, Miami, Florida 33149, USA
}

\begin{abstract}
There are limited quantitative data available documenting the natural, or non-epizootic, occurrence of scleractinian coral diseases over multiple years. Individual coral colonies exhibiting black band disease (BBD), white plague (WP), dark spots syndrome (DSS), and white band disease (WBD) were monitored 3 times per year on 5 south Florida reefs over a 2 yr period. Surveys included measurements of coral population composition, coral diversity, disease type, coral species affected, colony size, percent of colony affected, and the number of lesions or active infections per colony. Data on re-infections of the same colonies, multiple infections per colony, disease duration, diseaseassociated tissue mortality, and coral recruitment are also presented. A total of 674 coral colonies exhibiting coral diseases were tagged and monitored. DSS was the most common syndrome $(\mathrm{n}=620$ infected colonies), but BBD and WP infections caused the largest amount of coral tissue death. The only disease that exhibited a linear increase in incidence with elevated temperature was BBD. DSS and BBD were the most persistent conditions, and WP infections were comparatively short-lived, with obvious signs of disease typically disappearing after 2 to 3 mo. The only disease that caused total colony death as oppposed to partial mortality during the survey period was WBD. WP and DSS incidence was significantly positively correlated with the relative frequency of the species most commonly affected by each disease at each study site. Of the 61 colonies examined in the recruitment survey, only 5 scleractinian coral recruits were identified. The most commonly recorded colonizer of exposed coral skeleton was filamentous/turf algae, thus indicating the potential for a shift towards algal-dominated reef communities.
\end{abstract}

KEY WORDS: Coral diseases · Coral mortality · Florida Keys

\section{INTRODUCTION}

The frequency of occurrence, and the geographic and host species range, of scleractinian coral diseases has increased in the past decade (Santavy \& Peters 1997, Goreau et al. 1998, Hayes \& Goreau 1998, Richardson 1998, Harvell et al. 1999, Williams \& Bunkley-Williams 2000, Porter \& Tougas 2001). There is a rising concern over the ability of diseases to cause species shifts, restructure coral populations, and cause a decrease in coral species diversity (Aronson \& Precht 1997, Porter \& Tougas 2001, Bruckner 2002). In order to understand the role of coral diseases in effecting changes in community structure, it is necessary to quantify their temporal and spatial dynamics over multiple year time frames. The data available are usually limited in temporal scope and involve an examination of specific disease outbreaks (Dustan 1977, Gladfelter 1982, Feingold 1988, Dustan 1993, Peters 1993, Kuta \& Richardson 1996, Bruckner et al. 1997, Richardson et al. 1998a,b, Nugues 2002, Miller et al. 2003). There is a general paucity of information on the nonepizootic occurrence of coral diseases, as well as on the duration and severity of specific diseases in individual colonies (Bruckner 2002). Without this critical information, the management of coral reef ecosystems will be deficient. This study is a detailed survey of coral diseases over large, protected reef areas in Biscayne 
National Park and the Florida Keys National Marine Sanctuary in the upper Florida Keys reef tract (USA). Individual diseased colonies were tagged and monitored over time, allowing for the disease- and speciesspecific quantification of survival and mortality.

\section{MATERIALS AND METHODS}

Five reef sites in south Florida were surveyed for black band disease (BBD) (e.g. Antonius 1973, Rützler \& Santavy 1983, Rützler et al. 1983, Carlton \& Richardson 1995, Richardson 1996, Antonius 1988), white plague (WP) (e.g. Dustan 1977, Richardson et al. 1998a,b), dark spots syndrome (DSS) (e.g. Garzon-Ferreira \& Gil-Agudelo 1998, Goreau et al. 1998, Cervino et al. 2001, Borger 2005), and white band disease (WBD) (e.g. Gladfelter 1982, Aronson \& Precht 1997, 2001) in 2001 (April, July and September) and 2002 (April, July and September). Diseases/syndromes were identified utilizing published descriptions of each condition (Dustan 1977, Santavy \& Peters 1997, Richardson et al. 1998a,b, Garzón-Ferreira \& Gil-Agudelo 1998, Borger 2005) and U.S. government issued (National Oceanic and Atmospheric Administration, NOAA) disease identification cards (Bruckner \& Bruckner 1998a,b,c,d). Due to the fact that the different types of WBD and WP are based partly upon disease progression rates, these distinctions were not made in the surveys. Sites were selected randomly from a list of 16 reef sites in Biscayne National Park (BNP) and the Florida Keys National Marine Sanctuary (FKNMS) that were visited between 1998 and 2000 on unrelated field excursions. A pilot study was implemented during the summer of 2000 and spring of 2001 in order to become more familiar with the sites, construct site underwater maps, and to practice the survey methodology. The first complete survey of each site was executed in April 2001, and thus incidence values were acquired for July 2001. All surveys were conducted by a single observer, thereby eliminating interobserver bias. The sites were (from North to South): (1) Anniversary Reef (BNP), (2) Alina's Reef (BNP), (3) Marker 3 Reef (BNP), (4) Picture Reef (BNP), and (5) Algae Reef (FKNMS) (Fig. 1). Picture Reef was not surveyed in July 2001, and Algae Reef was not surveyed in September 2001 due to adverse field conditions, which made it impractical to survey all of the study sites during those months. All reefs ranged in depth from 3 to $7.5 \mathrm{~m}$ and were distributed across approximately $8500 \mathrm{~m}^{2}$ of reef area.

Coral population parameters (species richness, diversity, and percent cover) were assessed at each site using a quadrat percent cover method. A $1 \mathrm{~m}^{2}$ PVC quadrat was sub-divided into $100,10 \times 10 \mathrm{~cm}$ squares

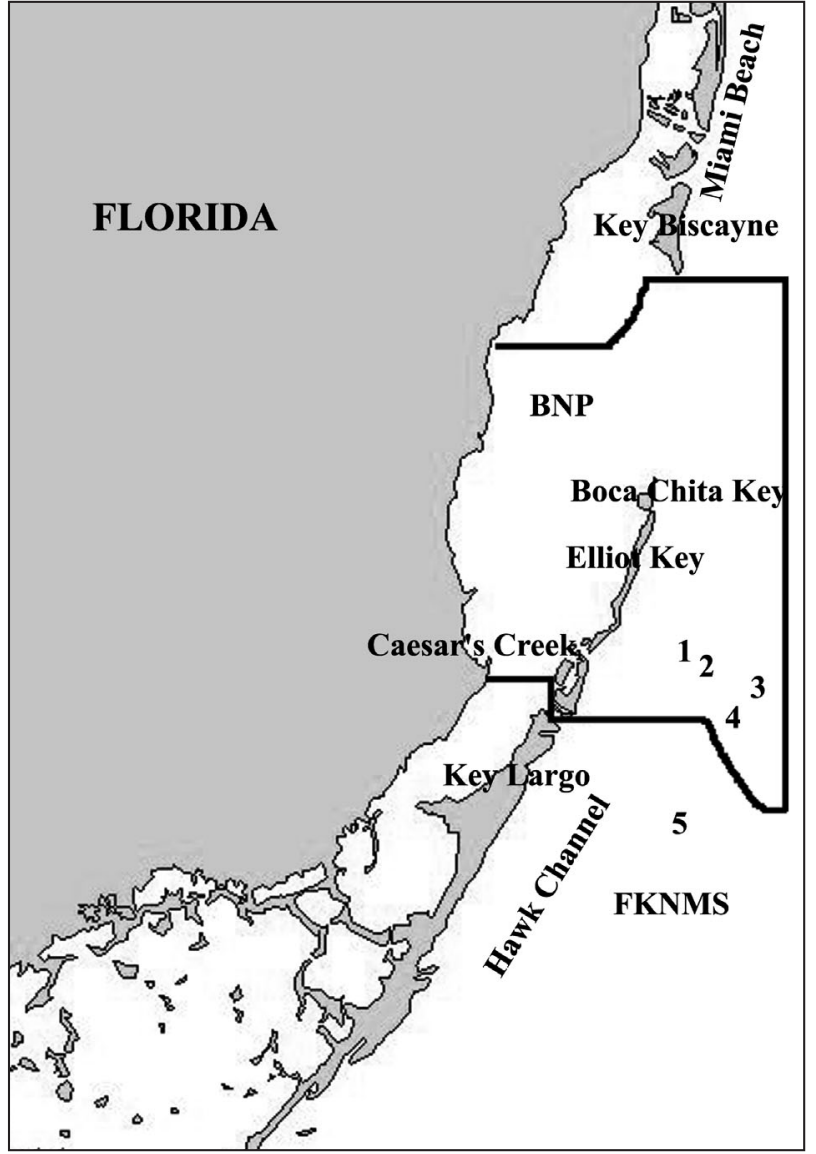

Fig. 1. Site locations in South Florida, USA. (1) Anniversary Reef (BNP), (2) Alina's Reef (BNP), (3) Marker 3 Reef (BNP), (4) Picture Reef (BNP), (5) Algae Reef (FKNMS). BNP = Biscayne National Park and FKNMS = Florida Keys National Marine Sanctuary

with twine. The quadrat was placed randomly upon the reefal substrate at each site 40 times (total area surveyed per site $=40 \mathrm{~m}^{2}$ ), using a list of random numbers for swim kicks and compass headings. Coral cover was estimated (visually) by counting the number of $10 \times$ $10 \mathrm{~cm}$ subdivisions filled by each species per each $1 \mathrm{~m}^{2}$. When a species was present within the quadrat but did not fulfill the minimum requirement of $0.5 \mathrm{sub}$ divisions, it was recorded as present $\left({ }^{\prime} \mathrm{P}^{\prime}\right)$ and used in the calculation of diversity indices (Shannon-Wiener Diversity Index $H_{\text {max }}^{\prime}=\log k_{i} k=$ number of species present).

Sites were sampled using SCUBA and surface diving. Site boundaries were established with markers (nails), and a pivoting line search pattern was used to survey the entire area for the presence of diseased coral colonies (range of individual site areas $=991 \mathrm{~m}^{2}$ to $2158 \mathrm{~m}^{2}$, see Table 1). The monthly survey of each site took approximately 5 to $7 \mathrm{~h}$. The use of underwater maps facilitated the location of diseased colonies in 
subsequent surveys and, in conjunction with the repetition and overlapping inherent in the survey technique, ensured the complete coverage of each site. In this study, disease occurrence is expressed as incidence, which is defined as 'the number of new cases of a specific disease occurring during a certain time period' (Stedman 2000). This definition is suggested for use by the Coral Disease and Health Consortium (National Oceanic and Atmospheric Administration, NOAA) (2003).

In each survey, all colonies exhibiting BBD, WP, DSS or WBD were tagged with roofing nails on non-living areas of the colony, adjacent to active infections. The following information was recorded: (1) type of disease, (2) coral species, (3) colony size, (4) percent of colony affected, and (5) the number of lesions, or active infections, per colony. A t-test was utilized to determine whether disease incidence differed among years. The percent of each colony affected by a disease was estimated visually using the following scale: $1=$ $1-20 \%, 2=21-40 \%, 3=41-60 \%, 4=61-80 \%$ and $5=$ $81-100 \%$. An accurate count of the number of lesions in excess of 30 per colony was difficult and time consuming, especially on days with adverse field conditions (e.g. poor visibility and high surge levels). Therefore, when a colony exhibited more than 30 lesions, a category of ' $>30$ ' was recorded, and a value of 30 was used in calculations. Cases of re-infections (of previously tagged colonies), multiple infections, and infection persistence or resolution were monitored throughout the survey period. Target species, defined as those most commonly affected by each disease, were identified in each survey year.

Colony size measurements were recorded as the maximum diameter multiplied by the maximum height of contiguous live tissue cover $\left(\mathrm{cm}^{2}\right)$. For comparison, 25 to 30 colonies of susceptible coral species were randomly measured at each site, regardless of disease status, and are referred to as 'population' corals in figures and text. A Chi-square analysis was used to compare the colony size classes of diseased and population corals. Colony sizes were divided into 5 size classes: (1) $0-100 \mathrm{~cm}^{2}$ (S, small), (2) $101-1000 \mathrm{~cm}^{2}$ (SM, small to medium), (3) 1001-4000 $\mathrm{cm}^{2}$ (M, medium), (4) 4001-5000 $\mathrm{cm}^{2}$ (ML, medium to large), and (5) > $5001 \mathrm{~cm}^{2}$ (L, large). The only species with a sufficient number of diseased colonies for comparison was Siderastrea siderea (DSS).

In September 2001 and 2002, total disease-related tissue mortality was recorded per infected colony at each site. Measurements were restricted to areas of bare skeleton adjacent to active lesions, with minimal or no algal growth, indicating recent tissue mortality. Disease incidence at each site was compared to relative target species densities, site coral diversity values
(Shannon-Wiener Index, $H^{\prime}$ ), and site percent coral cover, using the Pearson Product Moment Correlation statistic (r). Temperature data (acquired using a diver's depth gauge and BNP underwater datason database: Endico/YSI Meter, Model 6000, multi-parameter probe) from each survey month were also compared to disease incidence values to determine possible significant relationships using a linear regression statistic $\left(\mathrm{R}^{2}\right)$.

In September 2002, all tagged colonies (including some from the 2000 pilot survey) exhibiting disease induced tissue loss were surveyed for the presence of coral recruits on affected skeletal areas. A total of 61 colonies were examined, including colonies affected by each disease $(\mathrm{DSS}=34, \mathrm{WP}=16, \mathrm{BBD}=9, \mathrm{WBD}=$ $2)$. In addition to coral recruits, other general categories of colonizers were recorded and included: (1) filamentous algae, (2) macroalgae (predominantly Dictyota spp. and Halimeda spp.), (3) sponges, (4) boring sponges (predominantly Cliona sp.), and (5) tubicolous polychaetes. These data were collected to test Edmunds' (1991) hypothesis that coral diseases may create primary substrate for the recruitment and colonization of other scleractinian corals.

\section{RESULTS}

During the months surveyed from July 2001 to September 2002, there were a total of 674 diseased coral colonies, or 8 diseased coral colonies per $100 \mathrm{~m}^{2}$ of reef area. The estimated percent coral cover at all sites combined was $7.8 \%( \pm 2.9 \mathrm{SD}, \mathrm{n}=5)$, and the most dominant species were Porites astreoides, Siderastrea siderea, $P$. porites and members of the Montastraea species complex (Table 1). The most common disease/ syndrome was DSS $(\mathrm{n}=620)$. S. siderea was the species most susceptible to DSS and, therefore, was also the species with the highest number of diseased colonies $(\mathrm{n}=609)$ (Table 2). WP infected a total of 37 colonies, while BBD and WBD infected only 10 and 6 colonies, respectively. The species most commonly affected (i.e. target species) by WP in 2001 and 2002 was Diploria clivosa. However, the target species of BBD differed between years: Diploria strigosa in 2001 and Montastraea cavernosa in 2002. Acropora cervicornis was the only species noted with WBD during the survey period.

In 2001, BBD and DSS incidence decreased from July to September, while WP and WBD incidence increased (Fig. 2). In 2002, WP, BBD and DSS incidence increased from April to July. DSS decreased in September, WP increased, and BBD remained the same from July to September. DSS incidence was significantly higher in 2002 than in 2001 ( $t$-test, $t=-2.379$, 
Table 1. Coral population composition at each site, including \% coral cover, diversity $\left(H^{\prime}\right.$, Shannon-Wiener Index), and the area of site surveyed. Each species is followed by its relative abundance (\%) in $40 \mathrm{~m}^{2}$ surveyed per site (P: present). Ac: Acropora cervicornis, Aa: Agaricia agaricites, Ag sp.: Agaricia sp., Cn: Colpophyllia natans, Dsto: Dichocoenia stokesi, Dc: Diploria clivosa, Dl: Diploria labyrinthiformis, Dstr: Diploria strigosa, Ef: Eusmilia fastigiata, Mmir: Madracis mirabilis, Mar: Manicina areolata, Mme: Meandrina meandrites, Mann: Montastraea annularis, Mc: Montastraea cavernosa, Mfav: Montastraea faveolata, Mfr: Montastraea franksi, Od: Oculina diffusa, Pa: Porites astreoides, Pp: Porites porites, Sr: Siderastrea radians, Ss: Siderastrea siderea, Sb: Solenastrea bournoni, Si: Stephanocoenia intersepta

\begin{tabular}{|c|c|c|c|c|c|}
\hline & Anniversary Reef & Alina's Reef & Marker 3 Reef & Picture Reef & Algae Reef \\
\hline \multirow[t]{19}{*}{ Species (relative abundance, \%) } & $\mathrm{Pa}(46.3)$ & Mann (34.2) & Ss (39.2) & Mann (36.7) & Mfav (24.1) \\
\hline & $\operatorname{Pp}(20.2)$ & Mfav (16.0) & $\operatorname{Pp}(21.7)$ & $\operatorname{Pp}(22.4)$ & Pa (20.8) \\
\hline & Ss (18.4) & Ss (13.6) & $\mathrm{Pa}(7.7)$ & Dc (12.9) & Ss (17.5) \\
\hline & Dstr (6.9) & $\mathrm{Pa}(12.4)$ & Mann (7.0) & Ss (10.5) & Pp (11.8) \\
\hline & Dc (3.0) & Pp (8.3) & $\mathrm{Si}(4.5)$ & Mfav (3.9) & $\mathrm{Cn}(9.6)$ \\
\hline & Mc (2.3) & Dstr (6.1) & $\mathrm{Dl}(4.2)$ & Mc (3.4) & $\operatorname{Mc}(3.1)$ \\
\hline & Dsto (1.5) & $\mathrm{Ac}(3.6)$ & Mmir (3.7) & $\mathrm{Cn}(2.2)$ & Mann (2.5) \\
\hline & $\operatorname{Mfav}(0.5)$ & $\operatorname{Mfr}(1.9)$ & $\mathrm{Sb}(2.7)$ & Dstr (2.0) & Dsto (2.3) \\
\hline & Аа (0.5) & $\mathrm{Cn}(1.7)$ & Aa (2.2) & $\mathrm{Pa}(2.0)$ & Si (2.3) \\
\hline & Si (0.4) & $\mathrm{Dl}(0.6)$ & Dsto (2.0) & Dsto (2.0) & Dstr (1.9) \\
\hline & Ac $(\mathrm{P})$ & $\mathrm{Si}(0.6)$ & Mfav (1.5) & Mme (1.4) & Aa (1.5) \\
\hline & $\mathrm{Sr}(\mathrm{P})$ & Mc $(0.5)$ & Mme (0.7) & $\mathrm{Aa}(0.4)$ & $\mathrm{Dl}(1.0)$ \\
\hline & Dsto $(0.3)$ & $\operatorname{Sr}(0.7)$ & $\operatorname{Sr}(0.2)$ & $\operatorname{Sr}(0.6)$ & \\
\hline & Aa $(0.2)$ & Mc $(0.5)$ & & $\mathrm{Sb}(0.6)$ & \\
\hline & $\mathrm{Sr}(\mathrm{P})$ & Od (0.5) & & Mme $(0.4)$ & \\
\hline & & Ef $(0.3)$ & & Ef $(P)$ & \\
\hline & & Ag sp. (0.3) & & & \\
\hline & & $\mathrm{Cn}(0.3)$ & & & \\
\hline & & $\operatorname{Mar}(0.3)$ & & & \\
\hline Coral cover $(\%)$ & 9.8 & 11.8 & 5 & 6.3 & 6 \\
\hline Diversity $\left(H^{\prime}\right)$ & 0.65 & 0.85 & 0.86 & 0.81 & 0.91 \\
\hline Survey area $\left(\mathrm{m}^{2}\right)$ & 1835 & 1821 & 991 & 2158 & 1730 \\
\hline
\end{tabular}

Table 2. Total number of coral colonies of each species affected by each disease/syndrome between July 2001 and September 2002. These values represent newly infected colonies. Species abbreviations: see legend for Table 1

\begin{tabular}{|lcccc|}
\hline Species & DSS & BBD & WP & WBD \\
\hline Ss & 607 & - & 2 & - \\
Dc & - & 1 & 16 & - \\
Si & 13 & - & 1 & - \\
Dstr & - & 4 & 3 & - \\
Ac & - & - & - & 6 \\
Mc & - & 2 & 3 & - \\
Dsto & - & - & 4 & - \\
Mme & - & 2 & 1 & - \\
Cn & - & 1 & 1 & - \\
Pa & - & - & 2 & - \\
Pp & - & - & 1 & - \\
Mann & - & - & 1 & - \\
Aa & - & - & 1 & - \\
Dl & - & - & 1 & - \\
Total & 620 & 10 & 37 & 7 \\
\hline
\end{tabular}

$\mathrm{p}<0.05$, df = 16). However, there were no other significant differences in coral disease incidence among survey years. There was a significant positive, linear relationship between $\mathrm{BBD}$ incidence and water tem- perature $\left(\mathrm{R}^{2}=0.871, \mathrm{p}<0.05, \mathrm{df}=4\right)$. WP and WBD incidence was highest during the warmest survey month (September), but the relationship between disease incidence and water temperature was not significant when using a linear regression statistic $\left(\mathrm{R}^{2}\right)$.

When compared to other diseases, WBD affected the largest mean percentage of each colony (21 to $40 \%=$ estimation mean value $=2 \pm 1.9 \mathrm{SD}, \mathrm{n}=5$ ) (Table 3$)$, and DSS had the highest mean number of lesions per colony (mean $=17.44 \pm 10.72 \mathrm{SD}, \mathrm{n}=642$ ). When considering total disease-associated coral tissue mortality (i.e. across all sites and all survey periods), BBD and WP infections contributed to the largest amount of coral tissue death (Table 3). The disease that resulted in the least amount of tissue mortality was DSS. Only $17.9 \%$ of all colonies with DSS exhibited related tissue mortality. In most cases, the associated mortality was limited to a very small area of tissue at the center of the DSS lesions that was covered in small tufts of filamentous algae (indicating a slow progression of tissue death). Total tissue mortality increased from $3779.5 \mathrm{~cm}^{2}$ in 2001 to $10158.5 \mathrm{~cm}^{2}$ in 2002 . The species that experienced the largest total loss of tissue were Acropora cervicornis in 2001, and Diploria strigosa in 2002 (Table 4). 


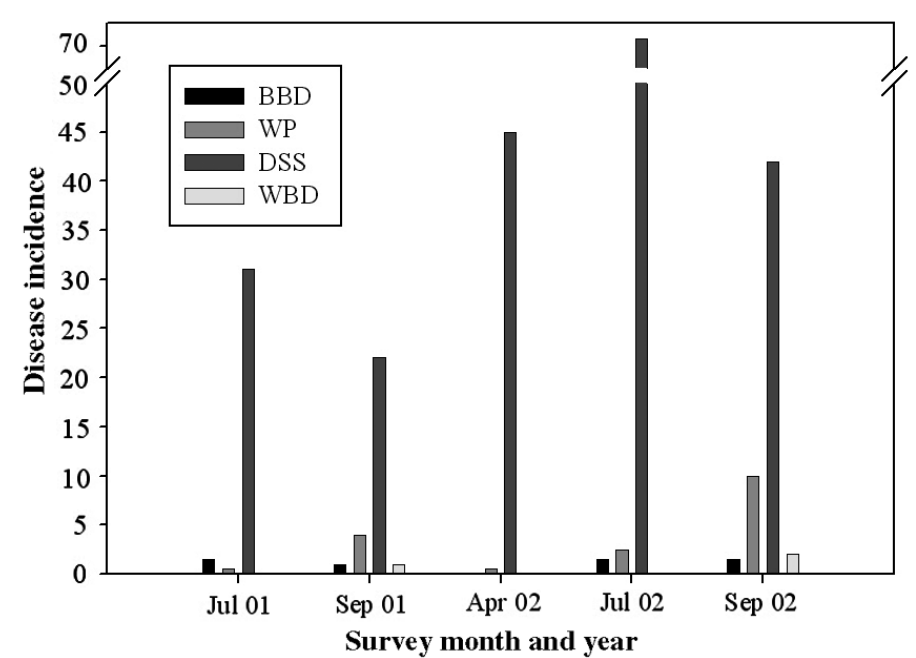

Fig. 2. BBD, WP, DSS and WBD incidence from July 2001 to September 2002. Mean temperature values were: July $2001=$ $28.9^{\circ} \mathrm{C}$, September $2001=28.4^{\circ} \mathrm{C}\left(\right.$ range $=21.5-30.5^{\circ} \mathrm{C}$ ), April $2002=26.4^{\circ} \mathrm{C}$, July $2002=30.1^{\circ} \mathrm{C}$, September $2002=$ $30.4^{\circ} \mathrm{C}$ (range $=21.9-32.4^{\circ} \mathrm{C}$ )

The size class frequency distributions of the Siderastrea siderea population and colonies with DSS were not significantly different $\left(\chi^{2}=1.72, \mathrm{p}<0.001, \mathrm{df}=3\right.$ ) (Fig. 3). Therefore, DSS did not predominantly affect any size class of $S$. siderea colonies.

DSS infections were more persistent than the other coral diseases. In 2001, $41 \%$ of the colonies tagged in July still had DSS lesions in September. In 2002, $50 \%$ of those tagged in April were still active in July, and $38 \%$ were still active in September. Thirty colonies with DSS in 2001 were noted to still have DSS in 2002. However, since no surveys were conducted in any year between October and March, it was impossible to determine the persistence of DSS between years. Comparatively, WP was much less persistent. Only 1 colony with WP in July 2002 was still active in September. The remaining colonies with WP in 2001 and 2002 were

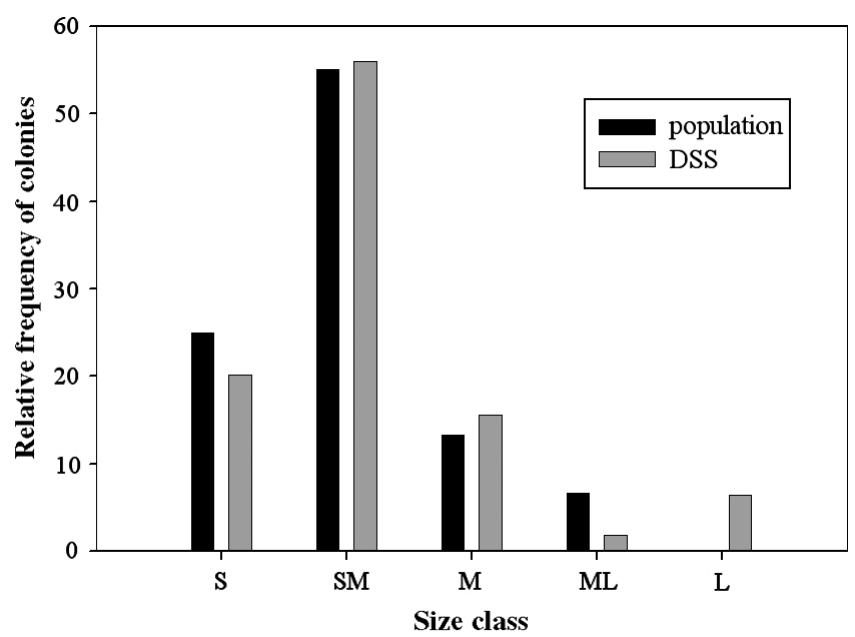

Fig. 3. Siderastrea siderea. Relative size class distribution of colonies exhibiting DSS and population colonies (includes measurements of both healthy and affected colonies). (S) $0-100 \mathrm{~cm}^{2}$ (small), (SM) $101-1000 \mathrm{~cm}^{2}$ (small to medium), (M) $1001-4000 \mathrm{~cm}^{2}$ (medium), (ML) $4001-5000 \mathrm{~cm}^{2}$ (medium to large), and (L) $>5001 \mathrm{~cm}^{2}$ (large)

Table 4. Total tissue mortality $\left(\mathrm{cm}^{2}\right)$ per species in 2001 and 2002. Species abbreviations: see legend for Table 1

\begin{tabular}{|lccc|}
\hline Species & $\begin{array}{c}\text { Tissue mortality } \\
2001\left(\mathrm{~cm}^{2}\right)\end{array}$ & $\begin{array}{c}\text { Tissue mortality } \\
2002\left(\mathrm{~cm}^{2}\right)\end{array}$ & $\begin{array}{c}\text { Total } \\
\left(\mathrm{cm}^{2}\right)\end{array}$ \\
\hline Dstr & 585 & 3275 & 3860 \\
Mme & 1350 & 2232 & 3582 \\
Mc & - & 2061 & 2061 \\
Ac & 1440 & 79 & 1519 \\
Dc & 182 & 1116 & 1298 \\
Dl & - & 756 & 756 \\
Dsto & 168 & 169 & 337 \\
Cn & - & 204 & 204 \\
Pa & - & 102 & 102 \\
Ss & 24 & 63 & 88 \\
Aa & - & 45 & 45 \\
Si & 30 & 10102 & 30 \\
Total & 3779 & & 13882 \\
\hline
\end{tabular}

Table 3. Mean ( \pm SD) percent of each colony affected by each disease/ syndrome, mean \pm SD number of lesions per colony, and disease-related tissue mortality for each disease (2001 and 2002 values combined). The mean $\%$ affected was estimated using the following scale: $1=1-20 \%$, $2=21-40 \%, 3=41-60 \%, 4=61-80 \%$, and $5=81-100 \%$

\begin{tabular}{|llcr|}
\hline Disease & $\begin{array}{c}\text { Mean \% } \\
\text { affected colony }\end{array}$ & $\begin{array}{c}\text { Mean \# of } \\
\text { lesions colony }\end{array}$ & $\begin{array}{c}\text { Tissue mortality } \\
\left(\mathrm{cm}^{2}\right)\end{array}$ \\
\hline BBD & $1.4 \pm 0.7(\mathrm{n}=10)$ & $1.6 \pm 1.4(\mathrm{n}=10)$ & 6409 \\
WP & $1.8 \pm 1.1(\mathrm{n}=34)$ & $1.2 \pm 0.9(\mathrm{n}=36)$ & 5916 \\
DSS & $1.4 \pm 0.8(\mathrm{n}=620)$ & $17.4 \pm 10.7(\mathrm{n}=642)$ & 38 \\
WBD & $2.4 \pm 1.9(\mathrm{n}=5)$ & $2 \pm 1.7(\mathrm{n}=5)$ & 1519 \\
\hline
\end{tabular}

free of active WP infections in each subsequent survey (time frame of approximately 2 to $3 \mathrm{mo}$ ). Two of the colonies with WP in 2002 were previously infected by BBD in 2000 (Montastraea cavernosa) and by WP in 2001 (Diplora clivosa).

BBD was relatively more persistent with most infections noted in July still active in September (2001: 89\% and 2002: $67 \%$ ). Only one Meandrina meandrites colony was infected in consecutive years, with disease cessation occurring between the years. WBD was only identified in September of both sur- 
vey years. In at least one case, the disease caused the death of the whole colony.

There was a significant, positive correlation between the relative frequency of identified target species $(\mathrm{WP}=$ Diploria clivosa and DSS $=$ Siderastrea siderea $)$ at each site and the incidence of WP (2002: $\mathrm{r}=0.948, \mathrm{p}$ $<0.05, \mathrm{df}=3)$ and DSS (2002: $\mathrm{r}=0.953, \mathrm{p}<0.05, \mathrm{df}=3)$. There was also a significant, negative correlation between total disease incidence and percent coral cover at each site (2001: $\mathrm{r}=-0.888, \mathrm{p}<0.05, \mathrm{df}=3$ ). There were no significant relationships between disease incidence and coral diversity.

A total of 5 coral recruits were identified on the 61 colonies examined in the recruitment survey, or 0.03 recruits colony ${ }^{-1} \mathrm{yr}^{-1}$. The recruits included 3 Siderastrea siderea and 1 Eusmilia fastigiata on a Colpophyllia natans colony infected with WP in 2000 and $1 S$. siderea on a C. natans colony infected with WP in 2001. The most commonly recorded colonizer of exposed coral skeletal surface was filamentous algae $(\mathrm{n}=59$ colonies), followed by macroalgae $(\mathrm{n}=21)$, boring sponges $(n=10)$, boring polychaetes $(n=2)$ and sponges $(n=1)$.

\section{DISCUSSION}

This study documents coral disease occurrence and dynamics across 2 consecutive summers. It differs from most other studies of coral disease distribution, in which surveys were conducted in response to specific disease outbreaks. These data indicate that coral diseases were variable in occurrence and species susceptibility between 2001 and 2002 at 5 sites in the upper Florida Keys (BNP and FKNMS). The number of colonies and species exhibiting disease and the total disease-related tissue mortality increased from 2001 to 2002.

\section{Disease dynamics}

Dark spots syndrome (DSS)

DSS affected the largest number of coral colonies in 2001 and 2002 when compared to other coral diseases. In contrast, Santavy et al. (2001) recorded DSS infections at most survey sites in the lower Florida Keys reef tract, but it was not the most common coral disease at any of the sites surveyed. The significant, 3 -fold increase in DSS incidence between years did not coincide with any obvious, visual environmental changes. Although the number of colonies with DSS was very high, and colonies with DSS displayed the highest number of mean lesions per colony, this syndrome caused the least amount of coral tissue mortality. Thus, the potential ecological impact of DSS is relatively low. The lack of a significant relationship between water temperature and DSS incidence in BNP and FKNMS supports the findings of a study of DSS in Dominica (Borger 2005). However, these findings contradict those proposed by Gil-Agudelo \& Garzón-Ferreira (2001), in which DSS incidence exhibited significant seasonal differences that were positively associated with increases in seawater temperature in Colombia. The only species identified with DSS in over $8000 \mathrm{~m}^{2}$ of south Florida reef area were Siderastrea siderea and Stephanocoenia intersepta. This contradicts other surveys in south Florida (Santavy et al. 2001) and Colombia (Garzón-Ferreira et al. 2001) in which multiple other scleractinian species were identified with DSS. Therefore, coral disease species susceptibility can vary greatly both inter- and intra-regionally, thereby emphasizing the need for a large range and number of survey areas.

White plague (WP)

WP affected the largest number of species $(\mathrm{n}=13$ scleractinian species), and Diploria clivosa was most commonly affected by WP in both 2001 and 2002. An additional 6 species were identified with WP in 2002 that had not exhibited WP in 2001. By comparison, $D$. clivosa was not identified with WP in a 2-yr study of other south Florida reefs (Santavy et al. 2001). Dichocoenia stokesi was identified as the species most commonly affected by WP Type II in the Florida Keys between 1995 and 1997 (Richardson et al. 1998a), and Siderastrea siderea was most commonly affected by WP in Dominica (Borger 2003, Borger \& Steiner 2005). This further supports the conclusion that coral susceptibility can vary greatly over small spatial and temporal scales.

WP contributed to $10 \%$ of the total disease-related coral tissue mortality in 2001 and $55 \%$ in 2002. Therefore, its potential ecological impact on reefs is high. However, WP is a transient coral disease. Most infections were inactive by the time of the subsequent survey (approximately 2 to 3 mo later). It is unclear why infections disappear, though Richardson et al. (1998b) noted that WP activity abruptly halted in midOctober during a 1995 outbreak, and suggested that this was due to a decrease in water temperature. Although all cases of WP in BNP and FKNMS caused only partial mortality, 2 colonies were re-infected in consecutive years (with disease cessation between years). In these cases, cumulative coral tissue mortality could likely lead to total colony death after multiple, annual infections. 
Although there was no linear relationship between WP incidence and water temperature during the survey period, there were more colonies infected with WP in September of 2001 and 2002 than any other survey months. August and September are the 2 warmest sea temperature months in the south Florida region. This may indicate that coral resistance and response to stress plays a major role in the disease etiology. It is possible that only after the coral has reached a threshold of temperature stress, with exposure over an extended period of time, does it become susceptible to infection by WP pathogens.

\section{Black band disease (BBD)}

The number of colonies infected with BBD was comparatively very low across all sites in both years. However, BBD infections accounted for $51 \%$ of the total coral tissue mortality in 2001 and $44 \%$ in 2002. Therefore, even low levels of BBD can be damaging to coral reefs by contributing to a relatively large amount of coral tissue death. The species noted to be most susceptible to BBD differed between years, which highlights the need for multiple year surveys. This is also important in terms of developing monitoring and management plans for coral reefs, because the effects of coral diseases, in terms of tissue mortality and species susceptibility, are variable across years and within regions.

BBD infections persisted between survey months, and BBD incidence was significantly related to water temperature. Phormidium corallyticum, the predominant BBD pathogen, photosynthesizes optimally between 30 and $37^{\circ} \mathrm{C}$ (Richardson \& Kuta 2003). Therefore, the direct relationship between pathogen virulence and temperature may explain the relationship between water temperature and BBD occurrence. There was only 1 colony that was infected with BBD in both 2001 and 2002 (with disease cessation between years). Therefore, the cumulative, yearly effects of BBD were less than those of WP.

White band disease (WBD)

The number of colonies infected with WBD was low across both years. However, the general paucity of Acropora cervicornis (the only species noted with WBD) at all sites may have contributed to the low number of infected colonies and a reduction in the critical threshold of host density for maintaining the disease. Despite the low number of colonies infected with WBD, the disease induced tissue mortality and disease severity ( $\%$ of each colony affected) was very high. WBD was the only coral disease noted to cause total colony death during the survey period, and A. cervicornis had the largest amount of tissue death recorded in 2001. WBD has contributed to the regional decline of $A$. cervicornis and A. palmata (Aronson \& Precht 1997, 2001).

\section{Disease incidence and coral population characteristics}

WP and DSS incidence was significantly related to the relative frequencies of target species (WP = Diploria clivosa and DSS = Siderastrea siderea) at each site, and there was a significant, negative correlation between percent coral cover and total disease incidence. Therefore, the occurrence of some coral diseases was more dependent upon the species composition at each site (in terms of the relative abundance of target species) than total host density. These findings agree with other studies in which the number of diseased colonies per study site was related to the abundance of specific susceptible species (Reigl 2002, Borger 2003, Borger \& Steiner 2005).

\section{Coral recruitment}

The recruitment survey was implemented in order to test Edmunds' (1991) hypothesis that within a spacelimited reef community, coral diseases create primary space for the colonization of other scleractinian corals. The recruitment surveys were limited to the exposed skeletal areas of affected colonies and, therefore, cannot be compared to more extensive surveys of recruitment, in which other substrates were examined for coral recruits. However, in similar studies, Edmunds (2001) found low rates of recruitment onto exposed coral skeleton ( 0.11 to 0.22 recruits colony ${ }^{-1} \mathrm{yr}^{-1}$ ) in the US Virgin Islands, and Kuta \& Richardson (1997) also found low recruitment rates (0.18 recruits colony ${ }^{-1} \mathrm{yr}^{-1}$ ) in south Florida. However, the recruitment rate was 3 times lower in this study. These discrepancies could be a result of differences in sampling techniques or may reflect documented regional and local spatio-temporal variation in coral recruitment (e.g. Chiappone \& Sullivan 1996, Smith 1997, Dunstan \& Johnson 1998, Moulding 2005). The exposed skeletal surface was more frequently colonized by algae, and Patterson et al. (2002) suggested evaluating the role of coral diseases in creating substratum for algal colonization.

Coral disease related tissue mortality does not appear to be important in promoting recruitment and propagation of reef-building corals. The rate of tissue destruction via coral diseases ranges from an average of $3 \mathrm{~mm} \mathrm{~d}^{-1}$ for BBD (Rützler et al. 1983), to $4-5 \mathrm{~mm} \mathrm{~d}^{-1}$ 
Table 5. Coral growth rates $\left(\mathrm{mm} \mathrm{yr}^{-1}\right)$ in the Caribbean (Florida, Bahamas and Puerto Rico) as recorded by Ma (1959). LE = lateral expansion, $\mathrm{H}=$ expansion in height/length

\begin{tabular}{|lc|}
\hline Species & Growth rate $\left(\mathrm{mm} \mathrm{yr}^{-1}\right)$ \\
\hline Acropora spp. & $64(\mathrm{H})$ \\
Agaricia agaricites & $7(\mathrm{LE})$ \\
Diploria clivosa & $5.5(\mathrm{H})$ and $8.5(\mathrm{LE})$ \\
Diploria labyrinthiformis & $7.4(\mathrm{H})$ \\
Diploria strigosa & $6.7(\mathrm{H})$ \\
Dichocoenia stokesi & $3.5(\mathrm{H})$ \\
Montastraea annularis & $5.5(\mathrm{H})$ and $7-10(\mathrm{LE})$ \\
Montastraea cavernosa & $5.7(\mathrm{H})$ and $7.5-9(\mathrm{LE})$ \\
Meandrina meandrites & $8.4-10.7(\mathrm{H})$ \\
Siderastrea siderea & $3.9(\mathrm{H})$ and $5-10(\mathrm{LE})$ \\
Stephanocoenia intersepta & $1.5-4(\mathrm{H})$ \\
\hline
\end{tabular}

for WBD (Davis et al. 1986), and a maximum of $2 \mathrm{~cm} \mathrm{~d}^{-1}$ for WPII (Richardson et al. 1998a). In comparison, coral growth rates are highly variable and are dependent upon various environmental factors, such as water chemistry, temperature, and turbidity (Hudson 1981, Lidz \& Shinn 1991). However, both indirect and direct measurements of coral growth establish average coral growth rates of approximately 6 to $14 \mathrm{~mm} \mathrm{yr}^{-1}$ of vertical accretion (see Table 5 for a summary of growth rates of specific species as measured by Ma 1959, Stearn \& Scoffin 1977, Stearn et al. 1977, Hudson 1981, Davies 1983, Davies et al. 1985, Neumann \& Macintyre 1985, and Buddemeier \& Smith 1988), with branching species growing at faster rates of several tens of $\mathrm{mm}$ $\mathrm{yr}^{-1}$ (Ma 1959, Buddemeier \& Smith 1988). Therefore, the rate of tissue destruction via coral diseases in the southern Florida reef tract is far greater than the rate of coral growth.

\section{Conclusion}

In conclusion, the coral diseases studied in this survey varied greatly over both spatial and temporal scales, especially in terms of species susceptibility. The re-infection of individual coral colonies between years will likely lead to a much greater loss of reef-building species than can be determined from a single-year survey. Thus, multi-year, comprehensive surveys are critical to the understanding of the dynamics of coral diseases and towards the development of sound management practices. In addition, if host resistance and selection remain consistent, there may be a shift in population and community structure towards reefs dominated by more disease-tolerant species. Management efforts should thus be focused on the species noted to be most susceptible to each disease and to the diseases that cause the most coral mortality. The rates of recruitment of scleractinian corals in south Florida do not seem capable of countering the rates of tissue destruction by coral diseases, and there is the potential for a shift in communities dominated by corals to those dominated by algae.

Acknowledgements. This study would not have been possible without the unwavering kindness and support of R. Curry, S. Viehman (Biscayne National Park), B. Valley and J. Delaney (Florida Keys National Marine Sanctuary). Biscayne National Park offered invaluable logistical and boat support, for which I am extremely grateful. The Florida Keys National Marine Sanctuary also donated boat-time, which enabled the survey of Algae Reef. I am indebted to A. Moulding and S. Viehman for consistent field support. Other individuals to whom I am grateful for assisting with fieldwork and/or access to sites are: R. Curry, D. Diresta, L. Richardson, B. Rosenheim and A. Diamond. This work was conducted under the following permits: BISC-00-025， BISC-2001-SCI-0013， BISC-2002-SCI-0006 (Biscayne National Park) and FKNMS-2000-053, FKNMS2001-074, FKNMS-2002-064 (Florida Keys National Marine Sanctuary). P. Glynn, S. Steiner, and L. Richardson kindly gave constructive comments regarding this manuscript.

\section{LITERATURE CITED}

Antonius A (1973) New observations on coral destruction in reefs. 10th Meeting Island Mar Lab Caribb (Abstr), University of Puerto Rico, Mayaguez:3

Antonius A (1988) Black band disease behavior on Red Sea reef corals. Proc 6th Int Coral Reef Symp, Townsville 6: $155-160$

Aronson RB, Precht WF (1997) Stasis, biological disturbance, and community structure of a Holocene coral reef. Paleobiology 23(3):326-346

Aronson RB, Precht WF (2001) Evolutionary paleoecology of Caribbean coral reefs. In: Allmon WD, Bottjer DJ (eds) Evolutionary paleoecology: The ecological context of macroevolutionary change. Columbia University Press, New York, p 171-233

Borger JL (2003) Three scleractinian coral diseases in Dominica, West Indies: Distribution, infection patterns and contribution to coral tissue mortality. Rev Biol Trop 51 (Suppl 4):25-38

Borger JL (2005) Dark spots syndrome: A scleractinian coral disease or a general stress response? Coral Reefs 24(1): 139-144

Borger JL, Steiner SCCS (2005) The spatial and temporal dynamics of coral diseases in Dominica, West Indies. Bull Mar Sci 77(1):137-154

Bruckner AW (2002) Priorities for effective management of coral diseases. NOAA Tech Memo NMFS-OPR-22, Aug 2002:1-54

Bruckner AW, Bruckner RJ (1998a) Disease and predation on scleractinian corals. Disease identification card, National Oceanic and Atmospheric Administration (NOAA), US Dept of Commerce, Washington DC

Bruckner AW, Bruckner RJ (1998b) Western Atlantic coral disease and predation: Star coral (Montastraea annularis, M. faveolata, M. franksi). Disease identification card, National Oceanic and Atmospheric Administration (NOAA), US Dept of Commerce, Washington DC

Bruckner AW, Bruckner RJ (1998c) Disease, predation and tissue anomalies affecting stony and soft coral. Disease iden- 
tification card, National Oceanic and Atmospheric Administration (NOAA), US Dept of Commerce, Washington DC Bruckner AW, Bruckner RJ (1998d) Disease and predation: staghorn and elkhorn coral (Acropora cervicornis and Acropora palmata). Disease identification card, National Oceanic and Atmospheric Administration (NOAA), US Dept of Commerce, Washington DC

Bruckner AW, Bruckner RJ, Williams EH Jr (1997) Spread of a black-band disease epizootic through the coral reef system in St. Ann's Bay, Jamaica. Bull Mar Sci 61:918-928

Buddemeier RW, Smith SV (1988) Coral reef growth in an era of rapidly rising sea level: predictions and suggestions for long-term research. Coral Reefs 7:51-56

Carlton RG, Richardson LL (1995) Oxygen and sulfide dynamics in a horizontally migrating cyanobacterial mat: Black band disease of corals. FEMS Microb Ecol 18: 155-162

Cervino J, Goreau TJ, Nagelkerken I, Smith GW, Hayes R (2001) Yellow band and dark spot syndromes in Caribbean corals: distribution, rate of spread, cytology, and effects on abundance and division rate of zooxanthellae. Hydrobiologia 460:53-63

Chiappone M, Sullivan KM (1996) Distribution, abundance and species composition of juvenile corals in the Florida reef tract. Bull Mar Sci 58:555-569

Coral Disease and Health Consortium (2003) National Oceanic and Atmospheric Administration (NOAA) webpage: www.coral.noaa.gov/coral_disease/cdhc.shtml.

Davies PJ (1983) Reef growth. In: Barnes DJ (ed) Perspectives on coral reefs. Clouston, Manuka, p 69-106

Davies PJ, Marshall JF, Hopley D (1985) Relationships between reef growth and sea level in the Great Barrier Reef. Proc 5th Int Coral Reef Symp, Tahiti 3:95-103

Davis M, Gladfelter E, Lund H, Anderson M (1986) Geographic range and research plan for monitoring white band disease. West Indies Lab USVI Nat Park, St. Thomas

Dunstan PK, Johnson CR (1998) Spatio-temporal variation in coral recruitment at different scales on Heron Reef, southern Great Barrier Reef. Coral Reefs 17:71-81

Dustan P (1977) Vitality of reef coral populations off Key Largo, Florida: recruitment and mortality. Environ Geol 2: 51-58

Dustan P (1993) Developing methods for assessing coral reef vitality: A tale of 2 scales. Proc Colloq on Global Aspects of Coral Reefs: Health, hazards and history. RSMAS, Univ of Miami, FL, p 38-44

Edmunds PJ (1991) Extent and effect of black band disease on a Caribbean reef. Coral Reefs 10:161-165

Edmunds PJ (2001) Recruitment of scleractinians onto the skeletons of corals killed by black band disease. Coral Reefs 19:69-74

Feingold JS (1988) Ecological studies of a cyanobacterial infection on the Caribbean sea plume Pseudopterigorgia acerosa (Coelenterata: Octocorallia). Proc 6th Int Coral Reef Symp, Townsville 3:157-162

Garzón-Ferreira J, Gil-Agudelo DL, Barrios LM, Zea S (2001) Stony coral diseases observed in southwestern Caribbean reefs. Hydrobiologia 460:65-69

Garzon-Ferreira J, Gil-Agudelo DL (1998) Another unknown Caribbean coral phenomenon? Reef Encounter 24:10

Gil-Agudelo DL, Garzón-Ferreira J (2001) Spatial and seasonal variation of dark spots disease in coral communities of the Santa Marta area (Columbian Caribbean). Bull Mar Sci 69(2):619-629

Gladfelter WB (1982) White-band disease in Acropora palmata: implications for the structure and growth of shallow reefs. Bull Mar Sci 32:639-643
Goreau TJ, Cervino J, Goreau M, Hayes R and 14 others (1998) Rapid spread of diseases in Caribbean coral reefs. Rev Biol Trop 46 (Suppl) 5:157-171

Kuta KG, Richardson LL (1996) Abundance and distribution of black band disease on coral reefs in the northern Florida Keys. Coral Reefs 15:219-223

Kuta KG, Richardson LL (1997) Black band disease and the fate of diseased coral colonies in the Florida Keys. Proc 8th Int Coral Reef Symp, Panama 1:575-578

Harvell CD, Kim K, Burkholder JM, Colwell RR and 9 others (1999) Emerging marine diseases: climate links and anthropogenic factors. Science 285: 1505-1510

Hayes RL, Goreau NI (1998) The significance of emerging diseases in the tropical coral reef ecosystem. Rev Biol Trop 46 (suppl) 5: 173-185

Hudson JH (1981) Growth rates in Montastraea annularis: A record of environmental change in Key Largo coral reef marine sanctuary, Florida. Bull Mar Sci 31(2):444-459

Lidz BH, Shinn EA (1991) Paleoshorelines, reefs and a rising sea: South Florida, USA. J Coast Res 7(1): 203-229

Ma TYH (1959) Effect of water temperature on growth rate of corals. In: Ma TYH (ed) Oceanographia Sinica. The World Book Co Ltd, Taiwan, p 116

Miller J, Rogers C, Waara R (2003) Monitoring the coral disease, plague type II, on coral reefs in St. John, U.S. Virgin Islands. Rev Biol Trop 51(Suppl 4): 47-55

Moulding AM (2005) Coral recruitment patterns in the Florida Keys. Rev Biol Trop 53(Suppl 1):75-82

Neumann AC, Macintyre I (1985) Reef response to sea level rise: keep-up, catch-up, or give-up. Proc 5th Int Coral Reef Symp 6:173-177

Nugues MM (2002) Impact of a coral disease outbreak on coral communities in St. Lucia: What and how much has been lost? Mar Ecol Prog Ser 229:61-71

Patterson KL, Porter JW, Ritchie KB, Polson SW, Mueller E, Peters EC, Santavy DL, Smith GW (2002) The etiology of white pox, a lethal disease of the Caribbean elkhorn coral, Acropora palmata. Proc Natl Acad Sci USA 99(13): 8725-8730

Peters EC (1993) Diseases of other invertebrate phyla: Porifera, Cnidaria, Ctenophora, Annelida, Echinodermata. In: Couch JA, Fournie JW (eds), Pathology of marine and estuarine organisms. CRC Press, Boca Raton, FL, p 393-449

Porter JW, Tougas JI (2001) Reef ecosystems: threats to their biodiversity. Encycl Biodivers, Vol 5. Academic Press, San Diego, CA, p 73-95

Reigl B (2002) Effects of the 1996 and 1998 positive sea-surface temperature anomalies on corals, coral diseases and fish in the Arabian Gulf (Dubai, UAE). Mar Biol 140(1):29-40

Richardson LL (1996) Horizontal and vertical migration patterns of Phormidium corallyticum and Beggiatoa spp. associated with black-band disease of corals. Microb Ecol 32:323-335

Richardson LL (1998) Coral diseases: what is really known? Trends Ecol Evol 14:438-443

Richardson LL, Kuta KG (2003) Ecological physiology of the black band disease cyanobacterium Phormidium corallyticum. FEMS Microbiol Ecol 43(3):287-298

Richardson LL, Goldberg WM, Kuta KG, Aronson RB and 5 others (1998a) Florida's mystery killer identified. Nature 392: $557-558$

Richardson LL, Goldberg WM,Carlton RG, Halas JC (1998b) Coral disease outbreak in the Florida Keys: Plague type II. Rev Biol Trop 46 (Suppl) 5:187-198

Rützler K, Santavy DL (1983) The black band disease of Atlantic reef corals: I. Description of the cyanophyte pathogen. PSZN I: Mar Ecol 4:301-319 
Rützler K, Santavy DL, Antonius A (1983) The black band disease of Atlantic reef corals. III. Distribution, ecology and development. PSZN I: Mar Ecol 4:329-358

Santavy DL, Peters EC (1997) Microbial pests: Coral disease research in the western Atlantic. Proc 8th Int Coral Reef Symp, Panama 1:607-612

Santavy DL, Mueller E, Peters EC, MacLaughlin L, Porter JW, Patterson KL, Campbell J (2001) Quantitative assessment of coral diseases in the Florida Keys: Strategy and methodology. Hydrobiologia 460:39-52

Smith SR (1997) Patterns of coral settlement, recruitment and juvenile mortality with depth at Conch Reef, Florida. Proc

Editorial responsibility: Albert Sparks,

Seattle, Washington, USA 8th Int Coral Reef Symp, Panama 2:1197-1202

Stearn CW, Scoffin TP (1977) Carbonate budget of a fringing reef, Barbados. Proc 3rd Int Coral Reef Symp, Miami 2: 471-476

Stearn CW, Scoffin TP, Martindale W (1977) Calcium carbonate budget of a fringing reef on the west coast of Barbados. I. Zonation and productivity. Bull Mar Sci 27:479-510

Stedman, TL (2000) Stedman's Medical Dictionary, 27th edn. Lippincott Williams and Wilkins, Philadelphia, PA, p 2098

Williams EH Jr, Bunkley-Williams L (2000) Major marine ecological disturbances of the Caribbean. Infect Dis Rev 2(3):110-127

Submitted: September 3, 2003; Accepted: July 25, 2005 Proofs received from author(s): November 7, 2005 